\title{
Protein pattern of cerebrospinal fluid in spasmodic torticollis
}

\author{
K. G. KJELLIN AND H. STIBLER
}

From the Department of Neurology, Karolinska Hospital, Stockholm, Sweden

SYNOPSIS The protein patterns found on isoelectric focusing and quantitative paper electrophoresis of cerebrospinal fluid were studied in three patients with spasmodic torticollis. Very alkaline end fractions were found on isoelectric focusing in the CSF-gammaglobulin region in each case. Alkaline end fractions in the CSF-gammaglobulin region with similar or same isoelectric points have also been observed in other extrapyramidal disorders, particularly Huntington's chorea, and in other neurological diseases, especially in multiple sclerosis. It has to be shown if these alkaline end fractions consist of the same or different compounds, conceivable constituents being mentioned. Examination of the CSF-protein pattern might help to distinguish organic from hysterical torticollis.

Isoelectric focusing is a new technique with high resolving capacity for proteins. The proteins are separated according to their isoelectric points. One procedure for thin layer isoelectric focusing in examining proteins of cerebrospinal fluid (CSF) in patients with multiple sclerosis was reported by Delmotte $(1971,1972)$, and another by Kjellin and Vesterberg (1972). Kjellin (1973b) and Kjellin and Vesterberg $(1972,1973,1974)$ also described the CSF protein patterns observed in subjects with other neurological diseases, especially demyelinating and infectious disorders, and Kjellin (1972, 1973a) described the xanthochromic protein patterns found in CSF from patients with haemorrhagic diseases of the nervous system.

Kjellin and Stibler (1974) in a preliminary report recently described the CSF-protein patterns found by isoelectric focusing and quantitative paper electrophoresis in patients with extrapyramidal diseases. In four of five cases examined with Huntington's chorea very alkaline end fractions were found on isoelectric focusing in the gammaglobulin region of the CSF, the fractions being very pronounced in two cases and moderately pronounced in the other two. Double fractions in the same alkaline range were observed in one case with post-encephalitic choreoathetosis. Two of three cases with Parkinsonism had slightly pronounced and questionable alkaline end fractions, while such a fraction was no observed in a case of (treated) Wilson's disease. Alkaline end fractions in the CSF-gamma globulin region with similar or same isoelectrie points have also been observed in neurologicaB diseases other than extrapyramidal disorders, especially in multiple sclerosis (Kjellin and Stibler, 1974; Kjellin and Vesterberg, 1974): However, it has to be shown if these alkaline end fractions consist of the same or different compounds.

The alkaline end fractions as well as fractions observed in other $\mathrm{pH}$ ranges on isoelectric focusing of CSF (Kjellin and Stibler, 1974), obviously demand further investigations of CSF proteins in extrapyramidal diseases. Spasmodic torticollis is generally classified with the extrapyramidal disorders, although psychogenesis is often considered to be important. To our knowledge, no pathological CSF findings have been reported in spasmodic torticollis.

The aim of this investigation was to examine whether any abnormalities in the CSF-protein patterns of patients with spasmodic torticollis might be found as compared with the CSF findings of 25 control subjects (psychoneurosis, cephalalgia, and uncomplicated epilepsy) assumed to have normal CSF as judged from cell count, protein concentration, isoelectric focusing, and quantitative paper electrophoresis. 


\section{METHODS}

The CSF samples were collected from three patients with spasmodic torticollis treated at the Department of Neurology, Karolinska Hospital, Stockholm. The assessment of the clinical data was based upon close examination of the clinical records, and the signs present were examined by one of the authors (H.S.) before the lumbar punctures.

\section{CASE HISTORIES}

R.A., age 46 years, male There was no hereditary neurological disease. He was essentially healthy until November 1973, when involuntary movements of the head to the right suddenly appeared. During three months there was a certain progress and thereafter some spontaneous improvement. At the examination five months after the onset he had typical spasmodic torticollis. No aetiological factor including psychogenesis could be established.

T.H., age 53 years, female There was no hereditary neurological disease. She had had thyrotoxicosis and rheumatic fever that left no residual disability 30 years earlier. In 1968 pain on the left side of the neck and slowly progressive involuntary movements of the head appeared. In 1974, the sixth year of illness, she has almost permanent deviation of the head to the right, jerky inconstant movements of the head and hypertrophy of the left sternocleidomastoid muscle. No definite aetiological factor has been established but psychiatric genesis has been proposed.

O.J., age 36 years, male There was no hereditary neurological disease. He was essentially healthy until December 1973, when progressive involuntary movements of the head to the left appeared. Upon the examination after four months of illness he had a typical spasmodic torticollis. No aetiological factor, including psychogenesis, could be established.

The CSF was obtained by lumbar puncture, performed in a standardized way (forenoon; patients

\section{TABLE 1}

ISOELECTRIC FOCUSING PATTERNS (a-f) OF CSF GAMMAGLOBULINS DIVERGING FROM 'NORMAL' FINDINGS IN 25 CONTROL CASES, VISUAL VALUATION WHERE THE CORRESPONDING SERUM PROTEIN PATTERNS HAVE BEEN TAKEN INTO CONSIDERATION

\begin{tabular}{cl}
\hline Pattern & Relative increase of proteins in regions $7-10$ (see Fig. 1) \\
\hline a & $8-10$, especially $9-10$ \\
b & $8-10$, rather uniformly \\
c & $7-10$, especially $8-10$ \\
d & $8-9$, rather uniformly \\
e & $7-9$, especially 9 \\
f & $7-9$, rather uniformly, usually very similar to a 'finger- \\
& print' of corresponding serum gammaglobulin \\
& pattern
\end{tabular}
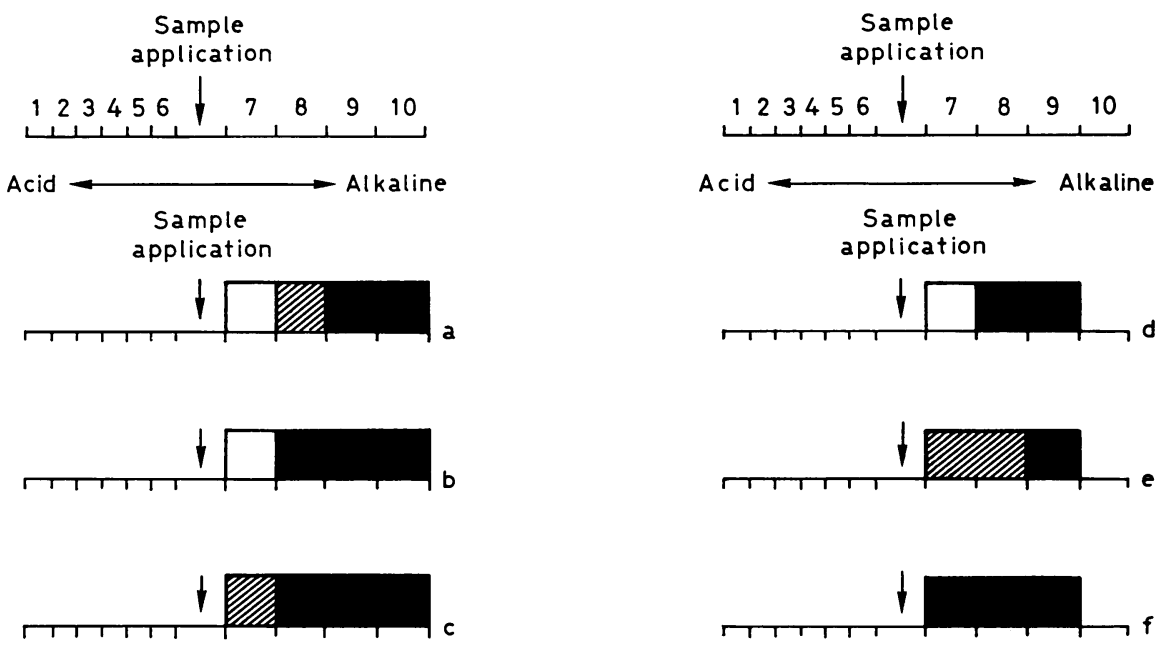

FIG. 1. The isoelectric focusing patterns (a-f) of CSF gammaglobulins as defined in Table 1. Black and hatched areas indicate relative increase of proteins, where hatched areas are used only to point out a less pronounced increase than in black areas in the patterns a, c, e. 


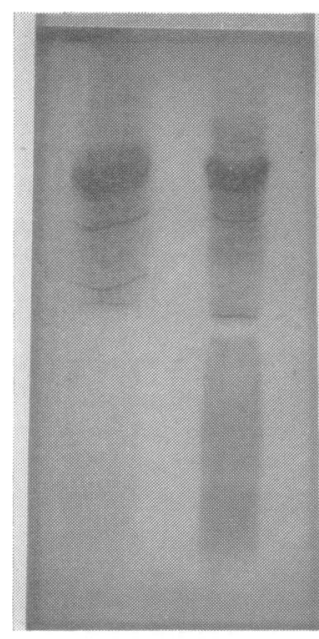

(a)

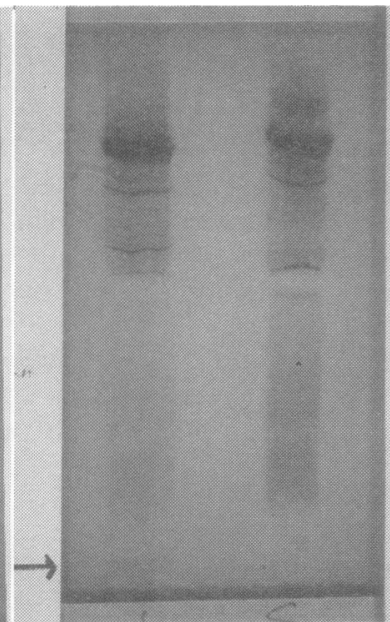

(b)

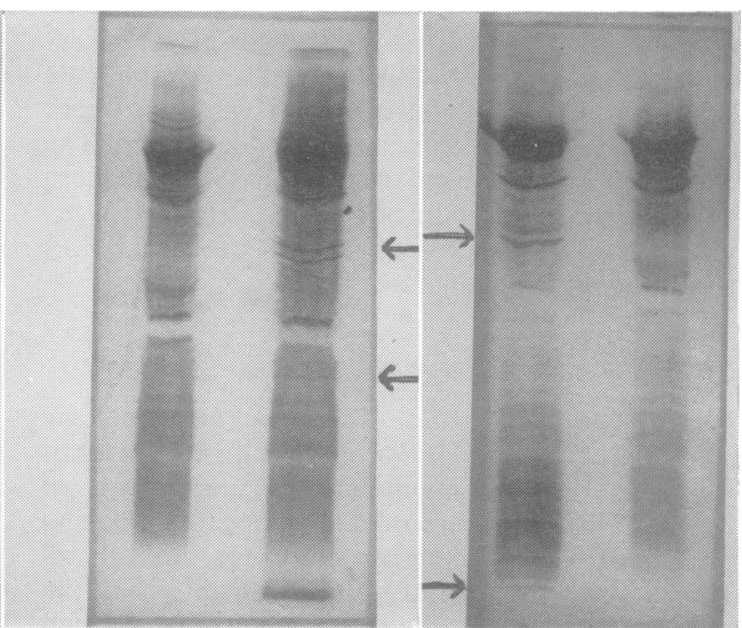

(c) (d)

FIG. 2. Gel isoelectric focusing patterns of CSF: (a) Normal CSF. Serum sample from the same patient to the right. (b) CSF pattern found in spasmodic torticollis (patient T.H.). Note the alkaline end fraction in the gamma globulin region (indicated by an arrow). The pattern is described in detail in Table 2. Serum sample from tho same patient to the right. (c) CSF pattern found in one case with Huntington's chorea. Note the pronounced 긍 alkaline end fraction in the gammaglobulin region. Fractions are also observed in region '4' and '7' (indicate $\mathrm{T}$. by arrows) and there is a moderately pronounced ' $f$ '-pattern (see Table 1 and Fig. 1 for explanationof symbols? Serum sample from the same patient to the left. (d) CSF pattern found in one case with multiple sclerosis. A ver alkaline end fraction (indicated by an arrow) in the ' $a$ '-pattern of the gammaglobulin region, and double fractions in the region ' 5 ' (indicated by an arrow) (see Table 1 and Fig. 1 for explanation of symbols). Serum samp from the same patient to the right. The anode was at the top and the cathode at the bottom.

fasting). Generally about $10 \mathrm{ml}$ CSF were withdrawn at one puncture. In addition to isoelectric focusing and quantitative paper electrophoresis the CSF was examined for cells and protein concentration. Serum samples were collected in parallel with the lumbar CSF samples and examined in a similar way.

The cells in the CSF were examined by routine microscopy and counted per $3.2 \mathrm{~mm}^{3}$. The CSF protein concentration was determined by a modification of the method of Lowry et al. (1951).

The quantitative paper electrophoretic examinations of CSF and serum were performed as described previously (see Gårde and Kjellin (1971) including references). The results of the CSF electrophoresis were classified according to characteristic 'patterns', or their probable combinations, after correction for the estimated influence of the serum protein distribution (Kjellin, 1969), and the CSF patterns were labelled with the symbols given by Gårde and Kjellin (1971).

The CSF samples were ultrafiltered (see Gårde and Kjellin (1971) including references) and concentrated about 10 times at which stage samples were withdrawn for isoelectric focusing, and the cerebrospinal fluids were then further concentrated to about 100 times for quantitative paper electrophoresis. The amounts $(20-40 \mu \mathrm{l})$ of the concentrated CSF used for isoelectric focusing were selected in order to get similar protein contents in all CSF samples examined. From each patient a serum sample diluted 10 times with physiological $\mathrm{NaCl}$ solution was applied side by side with the corresponding concentrated CSF sample on the acrylamide gel used for isoelectric focusing.

The isoelectric focusing procedure was performed in polyacrylamide gel as described by Kjellin and Vesterberg (1974).

The abnormal isoelectric focusing patterns of CSF gammaglobulins were labelled by the method of Kjellin (1973b) and Kjellin and Vesterberg (1974) (Table 1, Fig. 1).

\section{RESULTS}

The results of the CSF-protein examinations are 
TABLE 2

CSF PROTEIN PATTERNS FOUND IN THREE PATIENTS WITH SPASMODIC TORTICOLLIS*

\begin{tabular}{lccc}
\hline Patient & $\begin{array}{c}\text { CSF protein } \\
\text { conch } \\
(\mathrm{mg} / 100 \mathrm{ml})\end{array}$ & IF & PELF \\
\hline R.A. & 57 & $\begin{array}{c}\text { Narrow alkaline end } \\
\text { fraction; 'f'- } \\
\text { pattern (slight) } \\
\text { Alkaline end frac- } \\
\text { tion, moderately } \\
\text { pronounced; 'f } \\
\text { pattern (slight) }\end{array}$ & $\begin{array}{c}\text { I? (parallel slightly } \\
\text { pronounced in- } \\
\text { crease of serum-beta } \\
\text { and CSF beta } \text { - }^{-} \\
\text {globulin fractions) }\end{array}$ \\
O.J. & 43 & $\begin{array}{c}\text { Alkaline end frac- } \\
\text { tion, slightly pro- } \\
\text { nounced; 'f'- } \\
\text { pattern (slight). }\end{array}$ & B, slight \\
\hline
\end{tabular}

* The patients are identified from the case histories.

Symbols used : quantitative paper electrophoresis = PELF $; B=$ barrierdamage pattern; $I$ = 'immunopathic' pattern (see Gårde and Kjellin, 1971). Isoelectric focusing = IF : see Table 1 and Fig. 1 for explanation of symbols.

given in Table 2. Examples of the isoelectric focusing patterns are given in Fig. 2. Confirmatory re-examinations were performed by isoelectric focusing.

The quantitative paper electrophoretic examinations showed only slight or questionable abnormalities (Table 2). However, in two of the three patients the serum-alpha ${ }_{2}$ globulin fractions were slightly increased, and the serum-beta globulin fractions were at the upper limit of normal or slightly increased.

The cell examinations in CSF showed normal findings in all three cases examined.

\section{DISCUSSION}

Most recently very alkaline end fractions have been reported on isoelectric focusing in the CSFgammaglobulin region in four of five cases examined with Huntington's chorea, the fractions being very pronounced in two cases and moderately pronounced in the other two (Kjellin and Stibler, 1974). It may be mentioned that the patient with normal CSF-protein findings had the shortest duration of symptoms and the least pronounced extrapyramidal signs of all the five patients with Huntington's chorea. However, end fractions in the CSF-gammaglobulin region with similar or same alkaline isoelectric points have also been observed in neurological diseases other than extrapyramidal disorders, especially in multiple sclerosis (Kjellin and Vesterberg, 1974). These authors found such highly alkaline fractions in about $30 \%$ of their cases with clinically verified multiple sclerosis. It has to be shown that these end fractions with similar or same isoelectric points are composed of the same compound(s) - for example, gammatrace protein, immunoglobulins or their fractions, or decomposition products from destroyed nerve tissues.

CSF-protein abnormalities indicating some degree of damage of the blood-CFS barrier (slightly pronounced ' $\mathrm{f}$ '-patterns on isoelectric focusing and slightly pronounced ' $B$ '-pattern on quantitative paper electrophoretic examinations) were observed in all three cases examined with spasmodic torticollis. However, it seems rather improbable that the alkaline end fractions found might be caused by any barrier defect, as in cases with 'pure' barrier-damage patterns upon isoelectric focusing and quantitative paper electrophoresis, such end fractions have been detected infrequently (Kjellin and Stibler, 1974; Kjellin and Vesterberg, 1974). It may be mentioned that in the present three cases with spasmodic torticollis the most pronounced alkaline end fraction was found in the subject with the longest duration of symptoms.

Organic and hysterical torticollis are mostly very difficult to distinguish. It seems tempting to assume that an examination of the CSF-protein pattern in these cases might assist a true diagnosis.

\section{REFERENCES}

Delmotte, P. (1971). Gel isoelectric focusing of cerebrospinal fluid proteins: a potential diagnostic tool. Zeitschrift fïr klinische Chemie und klinische Biochemie, 9, 334-336.

Delmotte, P. (1972). Résultats comparatifs de l'électrophorèse en agar et de l'examen par électrofocalisation des gammaglobulines du liquide céphalo-rachidien. Acta Neurologica Belgica, 72, 226-234.

Gårde, A., and Kjellin, K. G. (1971). Diagnostic significance of cerebrospinal-fluid examinations in myelopathy. Acta Neurologica Scandinavica, 47, 555-568.

Kjellin, K. G. (1969). Kemiska likvorundersökningar inom neurologin. Svenska Läkartidningen, 66, 3939-3948.

Kjellin, K. G. (1972). Isoelectric focusing of xanthochromic CSF compounds. (Abstract.) In Proceedings of the Annual General Meeting of the Swedish Society of Medical Sciences, p. 300. Svenska Läkaresällskapet: Stockholm.

Kjellin, K. G. (1973a). Isoelectric focusing of protein compounds in the cerebrospinal fluid. Fourth International Meeting of the International Society for Neurochemistry, $\mathrm{p}$. 
462. Printed in Japan. (Edited by The Local Organizing Committee.)

Kjellin, K. G. (1973b). Isoelectric focusing of cerebrospinal fluid proteins in neurological diseases. (Abstract.) In Proceedings of the Annual General Meeting of the Swedish Society of Medical Sciences, p. 309. Svenska Läkaresällskapet: Stockholm.

Kjellin, K. G., and Stibler, H. (1974). The CSF-protein patterns in extrapyramidal diseases.-A preliminary report with special reference to the protein patterns in Huntington's chorea. European Neurology, 2, 186-194.

Kjellin, K. G., and Vesterberg, O. (1972). Thin-layer isoelectric focusing of cerebrospinal fluid proteins. A preliminary report with special reference to the diagnostic significance in multiple sclerosis. Proceedings of the 20th Congress of Scandinavian Neurologists, pp. 379-380, Universitetsforlaget: Oslo.

Kjellin, K. G., and Vesterberg, O. (1973). Acrylamide gel isoelectric focusing of cerebrospinal fluid proteins. In X International Congress of Neurology, Barcelona, 1973, (Abstracts.) Pp. 167-168. International Congress Series No. 296. Excerpta Medica: Amsterdam.

Kjellin, K. G., and Vesterberg, O. (1974). Isoelectric focusing of CSF proteins in neurological diseases. Journal of the Neurological Sciences, 23, 199-213.

Lowry, O. H., Rosebrough, N. J., Farr, A. L., and Randall, R. J. (1951). Protein measurement with the Folin phenol reagent. Journal of Biological Chemistry, 193, 265-275. 